\title{
Consumer Participation and Pro-Poor Regulation in Latin America
}

\author{
Cecilia Ugaz*
}

December 2002

\begin{abstract}
In spite of not being 'public goods' in the strict sense of the term, public provision has been a common way of supplying utilities services around the world. Among the major reasons underlying the dominant position of the public sector as the provider of infrastructure are the recognition of the economic and political importance of infrastructure for development, and the faith that government provision could offset market failures characterizing the utilities market. However, under public provision, universal access to the services remained elusive, with large sectors of the population being excluded. At the same time, the financing of services became a heavy burden on government budgets. As documented elsewhere in the research project, a major move towards privatization started in Latin America in the 1980s and early 1990s following the pioneering experiences of Chile's and the UK's infrastructure reform.
\end{abstract}

Keywords: utilities, privatization, public goods, regulation JEL classification: L4, L5, L9, H4, D1

Copyright (C) UNU/WIDER 2002

* IDS Sussex

This study has been prepared within the UNU/WIDER project on The Social Impact of Privatization and Regulation of Utilities in Latin America, which is co-directed by Dr Cecilia Ugaz, formerly of UNU/WIDER (Helsinki) and now at IDS Sussex, and Professsor Catherine Waddams Price, School of Management, University of East Anglia (Norwich).

UNU/WIDER gratefully acknowledges the financial contribution to the project by the Ministry for Foreign Affairs of Finland. 
UNU World Institute for Development Economics Research (UNU/WIDER) was established by the United Nations University as its first research and training centre and started work in Helsinki, Finland in 1985. The purpose of the Institute is to undertake applied research and policy analysis on structural changes affecting the developing and transitional economies, to provide a forum for the advocacy of policies leading to robust, equitable and environmentally sustainable growth, and to promote capacity strengthening and training in the field of economic and social policy making. Its work is carried out by staff researchers and visiting scholars in Helsinki and through networks of collaborating scholars and institutions around the world.

UNU World Institute for Development Economics Research (UNU/WIDER)

Katajanokanlaituri 6 B, 00160 Helsinki, Finland

Camera-ready typescript prepared by Lorraine Telfer-Taivainen at UNU/WIDER

Printed at UNU/WIDER, Helsinki

The views expressed in this publication are those of the author(s). Publication does not imply endorsement by the Institute or the United Nations University, nor by the programme/project sponsors, of any of the views expressed. 
Prior to privatization, the utilities sector in most Latin American countries was characterized by direct governmental intervention in pricing and investment decisions, and by nontransparent, nonindependent regulatory systems. As a result, tariffs associated with infrastructure services were twisted to obey political considerations, notably, average tariffs were set below long-run average costs. The results were disastrous for the financial viability of the enterprises, causing underinvestment, and declining quality. Lack of investment capacity seriously undermined network expansion needed to serve the increasing number of poor migrants coming to cities seeking opportunities for a better life. As a consequence, the proportion of the population in urban areas unable to access the networks grew over the years together with increasing user dissatisfaction at declining quality and the lack of responsiveness of public sector providers.

A desire to break this vicious circle of inefficiency and exclusion allegedly moved governments in the region to seek private involvement in sectors formerly dominated by state ownership - telecommunications, gas, electricity, water and sanitation, etc. Further motivation underlying the privatization drive was the willingness to attract private financing in order to alleviate the burden of public services on the budget. In addition, increased liberalization of services worldwide made it possible to attract substantive inflows of capital to these sectors, strengthening the foreign exchange position of the recipient countries. However, service access (coverage) is the outcome of supply and demand factors. The supply side represents the possibility of physically connecting to the network. The demand side is related to the household decision to connect. Besides the possibility of physically connecting to the network, a household's decision to connect is influenced by four factors: affordability, quality, relevance and fit. ${ }^{1}$ Change in ownership (from public to private) per se is not the solution for all the problems associated with access to services. We will argue in this paper, that the main problem so far is that the features characterizing public utility provision-absence of competition and lack of transparency in regulatory procedures - still characterize utility provision after nearly a decade of privatization.

\subsection{Access and affordability : can regulation be the answer?}

Private provision is the model chosen by governments in Latin America to solve the limitations of the public utility model. Given the nature of utility markets, regulatory mechanisms needed to be put in place. Utilities exhibit sunk costs, and sizeable investments are required to enter the market. Regulation in Latin America was primarily conceived to protect private investors from the risk of administrative expropriation from governments and to signal commitment to reforms. This way, the expectations of policy reversals would not defeat the original policy goal of attracting private investment (see Spiller 1996). Investors needed to be reassured that governments would not behave opportunistically, changing the rules of the game after the investment had been effected. Government failure to commit to a credible regulatory policy would, among other factors, deter private investment as private operators would hesitate to invest in places where there

1 Relevance refers to whether services address actual user needs and provide solutions to self-reported problems. Fit refers to whether service design and delivery mechanisms are sensitive to the livelihoods system, activities and constraints of users, especially the poor and vulnerable (Devereux and Cook 2000). 
is considerable uncertainty about the conduct of future economic policy. However, regulation is also needed because competition in the utilities market is difficult to enforce. Networks used to supply services to final users, as in the case of electricity and water, are natural monopolies. ${ }^{2}$ Under noncompetitive market conditions, regulatory mechanisms endeavour to protect consumers from monopoly power of utility operators.

Some policy interventions aiming to increase access to services were embedded in privatization deals and enforced through regulation-e.g. the imposition of investment targets, and universal service obligations (see Chisari et al. 2003). These interventions address the problem from the supply side, providing utility operators with incentives to expand the network. However, the problems on the demand side-preventing users from connecting to services (affordability) or forcing them to live in areas where connections are not enforced (relevance/fit) - remain mostly unsolved. This points to the level and the way tariffs of regulated utilities are set and whether service standards correspond to users' expectations and needs. It is beyond the scope of this study to address all the problems related to the demand side of the services. We will refer here basically to one of these aspects: affordability, and its link with regulation. Undeniably, utilities represent some of the most essential inputs into a decent standard of living. Ensuring access and affordability by low-income groups remains after few years of privatization one of the most challenging, albeit important, tasks in the agenda of public utility reform in Latin America.

The objective of this study is to broaden the discussion on utility regulation; we focus on regulatory institutions rather than regulated markets. Beyond the technical complexity involved in designing and implementing regulatory interventions, we focus on the governance of the regulatory process. Governance of the process refers to the way transparent and predictable regulatory systems can be put in place and sustained over time (Stern 1997:70). We focus in particular on one aspect of regulation governance: participation (Stern and Holder 1999). Participation in this framework means that all relevant parties in the process - governments, firms and consumers - contribute effectively to improve the quality of regulatory decisions. Participation would, in turn, increase the support from all the parties to the reform process and help to achieve more efficient and pro-poor outcomes. We will explore alternative regulatory arrangements allowing for enhanced consumer participation as stakeholders in the process of regulation. Giving voice and representation to consumers - poor consumers in particular-in regulation may help to offset the potential for capture embedded in the system and to allow the benefits of increased efficiency to spread to consumers under the form of tariff reductions.

The second section of this study considers the nature of utility markets after privatization that provides justification for the creation of regulatory bodies. We use for illustration the cases of telecommunications, electricity and water sectors in Argentina, Bolivia and Peru. The third section looks at regulation from an institutional perspective, and introduces the model of regulation by an independent agency which is widely followed in Latin American countries. In this framework, we also consider the tradeoffs between co-operation and capture and look at consumer participation as a mechanism to infuse accountability into the

\footnotetext{
2 Nowadays, technological progress is increasing the scope for competition in the utilities sector. This technical progress makes it possible to unbundle the production of the services to distinguish competitive from natural monopolistic activities. Such is the case in the electricity industry where generation is now considered a competitive activity, while the distribution to final users is still a natural monopoly.
} 
system. The fifth section-considering some limits to the formulation of regulatory policies in the context of the Latin American countries - concludes the study.

\section{Why regulation?}

Utility regulation has three main objectives: to protect consumers from monopoly power resulting from lack of competition in the utility markets; to support investment by protecting investors from arbitrary action by government; and to promote economic efficiency.

Can the markets for telecoms, electricity, water, etc. be competitive? The presence of economies of scale, economies of scope and sunk costs in the production/delivery of utilities is in principle detrimental to competition. On one hand, utilities have been long characterized as natural monopolies because the presence of economies of scale made the operation of more than one supplier in the market inefficient. On the other hand, economies of scope are also verified. This means that it is cheaper for the producer to supply not just one service, but a bundle of them-long-distance calls (international and national), generation and distribution of electricity, etc. This is a major reason underlying the vertical integration of these industries. Finally, the production and delivery of all the services entails sunk costs. In the case of electricity, telecoms and water, sunk costs arise because the investment in pipes or wires needed for distribution of the service is neither recuperable nor usable for other purposes. The presence of sunk costs makes it difficult for new suppliers to enter the market.

However, over recent years, innovation and technological progress have allowed the disaggregation of one sector into a range of activities, some of them offering greater possibilities of entry into the market. There is increasing scope for competition in the electricity industry, as well as, in some activities related to water-treatment, metering, etc. Another aspect of innovation, this time more dramatic, is seen in telecommunications, where the emergence of cellular telephones introduces the possibility of substitution in a market previously dominated by fixed technology.

Utilities combine two types of activities: naturally monopolistic, and potentially competitive (see Armstrong et al. 1995). Following this, authorities in charge of designing a privatization strategy first need to identify the industry structure and the scope for competition in order to implement privatization and regulation policies. In the utility sectors, there are obvious limits to competition especially in the distribution elements. Regulation is thus needed in these industries to curb monopolistic gains from noncompetitive activities.

\subsection{The nature of utility markets after privatization}

In the context of Latin American utilities, regulation was needed both because of the monopolistic nature of the activities related to service distribution, and because privatization agreements granted incumbent firms periods of limited competition and exclusive rights of operation in potentially competitive markets. For instance, in the case of telecommunications, in Argentina and Peru, exclusive rights were given to the incumbent to operate basic telephony services (local, national and long-distance calls) for a given period, with a possibility of extension. In both these countries the creation of regulatory bodies in the telecoms sector came after the privatization of the main telecoms provider. 
And in the case of electricity, regulatory bodies were created to oversee the operation of regional monopolies in the market of electricity transmission and distribution while competition was enforced in generation in both these countries. In Bolivia, electricity distribution firms were established as independent regional monopolies subject to tariff regulation and quality control.

In the case of water, Aguas de Illimani concession in La Paz-El Alto and Aguas Argentinas concession in Buenos Aires were granted exclusive rights to provide services in the concession area. Exclusivity illegalizes alternative water providers: communal standpipes, septic tanks, private wells, etc. Exclusive rights gives the concessionaire the property rights of virtually all water used in the concession area. In both cases, a regulatory bodyETOSS in Argentina and the Superintendencia de Aguas in Bolivia-were created to ensure the fulfilment of contractual arrangements (e.g. tariff setting, network expansion, quality, etc.).

There are at least three reasons underlying government adoption of 'competition for the market' (through a bidding process) and the creation of regional monopolies instead of the enforcement of direct competition when possible. First, was the need to maximize revenues from the sale of enterprises. Privatization in Argentina and Peru took place in the midst of macroeconomic strain and the governments were in dire need to close the budget deficit. Selling integrated monopolies increased the price that the incumbent private operator was willing to pay. Bolivia is an exception to the pattern observed in Argentina and Peru-with revenue maximization not being the primary objective of the government — which adopted a modality of privatization called 'capitalization'. Fifty percent of the value of the enterprises was sold to strategic investors and reinvested into the enterprises to increase their value. The majority of the remaining shares were transferred to a special fund linked administratively to pension funds. The government did not earn any cash from the transfer of the companies to the private sector (see Ewing and Goldmark 1994, and Barja and Urquiola 2003).

Second, periods of limited competition were also adopted to allow the utility operator to achieve certain targets for service expansion and quality improvement, requiring substantial new investment. At the time of privatization utility networks were immature (e.g. they exhibited huge unsatisfied demand). Thus, granting exclusivity rights made the operation financially more attractive and greatly reduced the risk facing the investor. For instance, in the case of the La Paz-El Alto water concession, the expansion mandate was a priority. Aguas de Illimani won the concession contract by bidding the highest number of new connections $(71,752)$ in the period to December 2001. Exclusive rights within the defined concession area were granted on one hand to reduce revenue risk eliminating competition from alternative water providers, and on the other hand to allow some crosssubsidization from high-volume/industrial consumers to low-volume/residential or poor consumers.

\subsection{The evolution of tariffs and consumer surplus}

Third, periods of limited competition were granted to allow the incumbent to rebalance tariffs from the preprivatization levels. Prevailing tariffs neither reflected costs structures nor allowed full cost recovery. Rebalancing during the period of limited competition would achieve the goal of reducing tariff distortions levelling the ground for competition. In all cases, privatization brought about new pricing schemes for the utilities. For the three 
countries and three utilities under study, the pattern of rebalancing was the same: an increase in the value of the rental (fixed charge) and a progressive decline in the value of the unit charges. The evolution of charges depended on the level of the pre-existing distortion, on the market structure prior to privatization, and on the degree of subsidies and cross-subsidies embedded in the tariffs. This pattern of rebalancing penalizes low-usage consumers, the poorest in particular. As a consequence, and in spite of improvements in the number of households connected to utility networks, substantive surplus losses have been observed among pre-existing consumers (e.g. those connected to the networks before privatization).

The evidence presented in Ugaz and Waddams Price (2003) shows that prices of the three utilities have often risen, adversely affecting low-income groups more than others. Even in the case of telecommunications, where allegedly with the presence of mobile phones the possibility of competition increases, surplus losses have been observed. In the case of Peru, there is also evidence that although the situation of access to telephones has improved in average, the efforts from Telefónica del Peru to increase coverage have been concentrated in the areas of the country with higher income per capita (Torero 2000). Also, the value of the rental and unit charges for local calls in Peru have been slow to decrease, exceeding those paid in other countries in the region like Chile and Argentina. All these developments raise questions about the redistributive impact of privatization of utilities and the effectiveness of regulation to protect poor consumers from monopoly power of private utility operators.

\section{Regulation from an institutional perspective: regulation as a public good}

Utilities are not public goods in the economic sense of the term. According to their consumption characteristics, telephones, electricity, and water can be classified as private goods. Private goods are excludable and rival. For instance, electricity and water are delivered through networks (water pipes, electric grids, etc.) designed to satisfy the demand of several users. Access/exclusion depends on being connected to the network or not. The degree of rivalry depends on the additional costs imposed on other users (or on the provider) when an extra unit of service is consumed. Also, as networks operate close to full capacity consumption of the services becomes rival.

Nevertheless, regulation can portray the attributes of public goods: nonexcludability and nonrivalry. Regulation ought to be nonexcludable. This attribute of publicness is not a fixed attribute-it depends on policy design. It is sometimes difficult to characterize regulation as a public good because more often than not, the public bad, regulatory capture, is present. For regulation to be a public good, regulatory tools - the rules, their meaning and expected outcomes - should become a matter of public concern. They should enjoy broad public acceptance and, more importantly, they should apply to everyone. When regulation excludes the concerns of any of the actors in the process, it becomes a public bad. We can distinguish three main groups or actors in the process of utility regulation: the government, private utility operators, and consumers. ${ }^{3}$ We recognize that the government and private companies have enough bargaining power to shift the balance of regulation to favour their own interests. Consumers in general are less homogeneous and more difficult

\footnotetext{
3 We can further distinguish private utility operators as foreign or local companies. In the case of consumers, we can distinguish low-income and high-income consumers.
} 
to organize as a group. Therefore, consumers may face more difficulties in having their demands translated into policies.

Regulation should be nonrival. The existence of an additional consumer being subjected to the same regulation does not entail any disadvantage to existing users. On the contrary, when regulation is extended to additional consumers, it creates positive externalities. For instance, regulation that improves access to water and sewerage benefits not just the individual, but the entire community by lowering health risks. There is also a particular type of externality known in the telecoms business as 'network externality' by which the desire of an individual to subscribe to a network depends on who else subscribes to it. In that case, regulation that ensures universal access to telephones may benefit all existing consumers because they are able to communicate with more users. These two attributes: publicness and nonrivalry, can also be associated with the existence of institutions. According to North, institutions are the rules of the game in a society. They are composed of formal rules, informal constraints, and of their enforcement characteristics. Formal rules can be changed overnight by the polity, while informal constraints change very slowly (North 1997:1). Institutions enhance efficient market exchanges by lowering transaction costs and lending credibility to commitments.

In the case of utilities, transaction costs arise because of the presence of bulky investments and sunk costs. Furthermore, asset specificity often characterizes the production of these services. This means that once investment is effected, it is nonreversible and difficult to divert assets to alternative uses. The irreversible nature of investments makes these sectors prone to 'opportunism'. Regulatory institutions fulfil a dual role; to provide discipline and to license. Institutions curb opportunistic modes of action and provide actors with socially validated standards (Offe 1996).

\section{The model of regulation by an independent agency}

... it is not self-evident that simply because the good is 'public' ... it should be provided by the government (Drazen 2000:373)

Regulation is a public institution (not a government institution) because it operates in public space and act on public issues. Latin America, by establishing independent regulatory agencies, has in general adopted the UK model of regulation. The agency is created by law which outlines its mandate: gather information on production costs and investment, calculate prices and tariffs, evaluate the behaviour of different players in the market, provide operating licenses, etc. In addition, the agency bases its actions on the sector's legal framework. This legal framework introduces a valid code of provider conduct against which their performance will be assessed. The regulatory agency also provides incentives for efficiency through its tariff system which is revised periodically.

But how independent should the agency be? Or more exactly, independent of what? The definition and degree of independence of the regulatory agencies vary across countries and are also a matter of heated debate. Following Blinder (1997, 1998), we consider that independence means detachment from (partisan) politics. If the regulatory agency is not 
independent from politics, the objectives of regulation may get confused with other aims. ${ }^{4}$ There are two important reasons to isolate regulation policy making from politics. First, regulation of utilities is a technical field where specialized as opposed to political knowledge is needed. And second, policy decisions taken by expert regulators would require a long time to bear results, and long time horizons are not usually associated with politicians.

One important aspect of designing regulatory institutions is to decide whether there should be an individual regulator or a committee. Appointing regulatory committees is more common than appointing a single regulator. However, both models have arguments in favour and against that should be scrutinized in light of particular conditions in each country (Guash and Spiller 1999). On one hand, it has been argued in the UK, where there is an individual regulator by sector - the director-general - that individual decision making is superior in terms of speed and decisiveness. A system with a single regulator is also seen as less bureaucratic than a collegiate system (Baldwin and Cave 1999). On the other hand, it is argued that a regulatory board or a committee will avoid placing unnecessary pressure on just one person, reduce unpredictability of individual behaviour, and introduce the possibility of more transparency through a process of open deliberation. It is also argued that a number of regulators will bring more and diversified experience to the process. However, the composition of the committee needs a very careful examination and is bound to be contentious as we will see below.

\subsection{Independence versus opportunism}

In countries with a long history of populism, as it is the case in Latin America, one of the aims of regulation is to protect private investors from the risk of 'administrative' expropriation (Spiller 1995). ${ }^{5}$ In this framework, the regulator's lack of political independence implies that in the long-run (government) gains from privatization would be smaller as private investors, expecting lower profits because they fear such expropriation, would bid less for public companies. Expectations of political interference in the process of regulation would also limit the investments that utility operators are willing to commit to specific assets, which subsequently causes inefficiency and higher prices. Finally, low and inefficient investments would build up pressure to reverse the privatization process, as prices for services would increase but the problems of exclusion and congestion would not be solved. Thus, the case for an independent regulatory agent in the Latin American context is given by the real challenge to design a structure that fosters policy credibility, and commitment, and limits government intervention in price setting (Spiller and Savedoff 1999).

There are some factors that can increase the probability of independent action by a regulatory body. These include:

i) a clear mandate established by law;

\footnotetext{
${ }^{4}$ For example, if the regulator is not independent, the objective of regulating tariffs may be the fight against inflation. Although perfectly valid, the latter can be achieved through other means. See Fernández Ordoñez (1997).

5 Tariffs, when set below long-run average costs, de facto expropriate companies' sunk costs.
} 
ii) formal procedures to appoint top officials involving both executive and the legislative powers;

iii) protection of regulators against arbitrary removal;

iv) a system of remuneration to attract and retain competent and well-qualified staff;

v) mechanism for autonomous and reliable financing beyond central budget control, etc.

In view of this, independence is relatively easy to achieve in constitutional regimes where parliament plays an important role, or where there is some balance of powers. ${ }^{6}$ Independence is more difficult to achieve in presidentialist regimes as witnessed in Latin American countries, where executive power is very strong.

We have attempted to verify the requirements for an independent agency in the case of Argentina, Bolivia and Peru. In these countries, as part of sector reforms, regulatory agencies were created and given a clear mandate and full autonomy. The regulatory bodies are provided with autonomous sources of financing which makes them independent of the central government budget. Regulators are appointed for a fixed term and can be removed from office before the end of the term only in the event of demonstrated misconduct. With regard to the system of remuneration, regulators are not affected by wage scales affecting public employees, which leaves room for salary adjustment according to performance. However, the designation of the regulators is vested with the executive power of the country. Only in Bolivia does the law explicitly stipulate that the candidates first be voted by majority at the senate. ${ }^{7}$ There also appears to be some difficulty in achieving a restriction on ministerial control over the process of regulation. This is true in the Argentinean telecoms sector where, in spite of regulatory responsibilities being assigned to a newly created agency, the Secretariat of Communications (Comisión Nacional de Telecomunicaciones) previously in charge of regulating the sector, has managed to retain some power (see Delfino and Casarin 2003).

\subsection{Co-operation versus capture}

Independence defines the relationship of the regulator with respect to the government. But what about the relationship between the regulator and firms?

The problem of capture-e.g. when the regulator acts on behalf of the incumbent industry and not on behalf of consumers or potential entrants in the industry - is arguably embedded in the process of regulation because some degree of co-operation (trust) between the regulator and the firm is needed throughout the process. Co-operation and trust allows the agency to save on cumbersome/expensive regulatory supervision and monitoring. Cooperation provides the firm with some flexibility to reach efficiently the objectives set by the regulator. Joint co-operation between the regulator and the firm is Pareto optimal. However, according to Ayres and Braithwaite (1992) the conditions to foster co-operation are also the conditions that promote the evolution of capture and corruption. The potential

\footnotetext{
6 The USA Federal Reserve Board (FED) is one of the most famous examples of an independent policy making body. The members of the board of directors of the FED are designated by executive appointment and confirmed by congress. However, once the board members take up their functions, they are neither obliged nor expected to obey the president nor congress (see Blinder 1997).
} 
for capture is determined by the following factors: (i) a small number of companies operating in the market; (ii) a sector-specific regulator rather than a multi-industry regulator where inspectors acting on behalf of the regulator are in regular contact with the same client company; (iii) a high proportion of inspectors with a background in the regulated industry.

The potential for capture is thus verified in all the cases we are studying. Firms operating in the sectors, for the reasons outlined in the previous section, are monopolistic. Also, there is a notorious lack of qualified personnel to work in the agencies. In that case, it is unavoidable that many professionals will come with prior experience from working within the industry. ${ }^{8}$ However, the important presence of foreign companies bringing their own personnel may counterbalance the risk of having former colleagues on both sides of the negotiating table. In both Argentina and Peru, regulatory agencies are industry-specific. ${ }^{9} \mathrm{~A}$ national regulatory commission (SIRESE) was created in Bolivia; the commission contains four sector-specific national superintendences (telecoms, electricity, water and sanitation and hydrocarbons). The system tries to achieve policy coherence across sectors and to isolate the agency from undue government or industry influences (Guash and Spiller 1999).

One of the main problems encountered in the regulation of utilities is the differences in bargaining power between the regulator and the firm. The process of liberalization of trade in services worldwide is marking the supremacy of big players in the utility markets. Twothirds of water supply contracts around the world are held by French operators: SuezLyonaisse des Eaux, Vivendi Water and SAUR (Schwartz et al. 2001). These firms are also leading the consortiums operating the water concessions of Buenos Aires and La PazEl Alto. The Spanish telecoms company, Telefónica, and the energy firms, Repsol and ENDESA, are leading investors in Latin American countries. Telefónica is the largest nonfinancial corporate investor in the region. Since their own privatization, Repsol, Telefónica and ENDESA belong to a complex financial and industrial network. All these companies have the same shareholders: Banco Bilbao Vizcaya (BBV), Banco Santander Central Hispano (BSCH), Argentaria, and La Caixa. ${ }^{10}$ These banks have an important presence in the financial systems in Latin American countries. This extensive crossownership has resulted in an enormous concentration of power that may have the capacity to distort entry, competition and regulation both in Spanish and in Latin American markets (see Arocena 2003). Regulation under these circumstances becomes a daunting task.

\footnotetext{
7 In Bolivia, the individual regulator-superintendente - is elected by the president from three candidates endorsed by at least two-thirds of the members of the senate (Law No. 1600/28 October 1994) (SIRESE 1994).

8 For instance, in the case of ETOSS (the water regulator in Argentina) most of the 110 employees are former OSN (the state-owned water utility company) workers (Loftus and McDonald 2001).

${ }^{9}$ For an analysis of the differences between industry-specific as opposed to multisectoral agencies, see Smith (1997).

10 Oxford Analytical Daily Brief August 1999.
} 


\section{Consumer participation}

Participation is about the involvement of all stakeholders through a process of communication and negotiation to influence decisions that affect their lives. Participation leads to the creation of accountability. (Tandon 2002:64)

When decisions in the regulatory agencies are taken by a committee- the board of regulators - as in Argentina and Peru, the issue is how to decide the composition of the board, and in particular, how to institutionalize consumer participation. We would like to stress that consumer participation in regulatory process is important to balance the process and frustrate the potential for capture embedded in it.

But, which type of participation? According to Goetz and Gaventa (2001), citizen participation in policy making and in scrutinizing policy implementation can take three different modalities: consultation, representation and influence. These different modes represent the depth of engagement in policy making allowed to citizens. The first modality, consultation, involves opening arenas for dialogue and information sharing. It can vary from one-off to ongoing consultation. The second modality, representation, involves institutionalizing regular access for certain groups in decision making. The third, influence, allows citizens to achieve a tangible impact on policy making and the organization of service delivery (Goetz and Gaventa 2001:9).

In the case of Peru, for instance, some form of consultation is contemplated in regulation law. ${ }^{11}$ This means that all the decisions taken by the regulator should be made public, seeking feedback from consumer representatives before the implementation. But is consultation enough?

A controversy (during summer 2001) about the productivity factor (the $X$ factor) to be applied by Telefonica del Peru to the calculation of tariffs shows that this type of ex post participation is not unproblematic. The discrepancy was not only on the value of the $\mathrm{X}$ factor-which has important consequences on the final tariffs charged to consumers-but on the process of consultation with civil society and consumer associations. One element highlighted by the Peruvian ombudsman is, for instance, the timeframe allowed for such consultation to take place. In Peru, the process of consultation lasts for about two months while in the UK a similar process of consultation would last for about 30 months (see $E l$ Comercio 2001, Gestion 2001, and GRADE 2001). This controversy casts some doubts about the effectiveness of consultation to engage consumers in policy making and also confirms that 'consultation does not lead on its own to policy influence' (Goetz and Gaventa 2001:9). We would argue here that participation and voice at the negotiating table (through the appointment of a consumer representative to the board of regulators) is actually more effective to enforce transparency and to offset the potential for capture than consultation.

There are reasons for this (see Ayres and Braithwaite 1996). The presence of consumers in the regulation process crucially affects the regulated firm's ability to capture because the firm must secure support of the agency, as well as the consumer representatives, to be effective. The presence of consumer representatives increases the cost of lobbying for the firm. However, what happens in the case of utility sectors where the dominant players in

11 DS 032-2001-PCM. 
the field are transnational corporations who can easily absorb the cost of lobbying? The only way to deal with the problem is to make the process of consumer representation contestable and to have as much transparency as possible in the regulation process so as to denounce any attempt of capture.

Perfect contestability means that there will be competition among different consumer associations to be the one representing consumers in regulation. This is a necessary assumption, since consumers are not homogeneous, and poor consumers in particular are likely to be a highly heterogeneous group. So, there would be a large number of consumer associations willing to take up responsibility of representing consumers. If that is the case, the number of 'bribes' the company would have to pay to capture 'the' representative is quite considerable. Moreover, not all consumer associations have the same lobbying technologies. Consumer associations are usually NGOs encompassing many different ideals. By increasing the number of potential entrants to the process of selecting one group to represent consumers, the chances that at least one group will not be prone to capture increases. The lobbying expenses incurred by the firm trying to ensure support with all the other groups will be wasted.

It is useful at this stage to note the experience of the UK with respect to representation of consumer interest ${ }^{12}$. As we mentioned already, the UK has a system of individual regulators, but arrangements for consumer representation were established at the time of privatization. Consumer representation in the UK followed two models: the integrated and the independent models. In the case of electricity and water, consumer bodies-electricity consumer committees (ECCs) and customer services committees (CSCs)-were established within the regulatory office (integrated model), with the regulator being responsible for their funding and appointments. In the case of gas, the Gas Consumer Council (GCC) was established as external to the regulator (independent model), with the support of the secretary of state.

Nowadays, consumer representation in the UK is being reviewed as part of a broader reexamination of regulation policy undertaken by the Labour government (Waddams and Young 2003). The review aims at developing a consistent regulatory framework for the utilities. Notably, the review proposes a common model for consumer representation across the utilities. This new model consists on the establishment of independent consumer advocacy bodies. The recent creation of Energywatch, a single independent consumer council for electricity and gas sectors, may herald the future model of consumer representation in the network utilities in the UK. Independence versus integration, the scope of representation (whom to represent), national versus regional structure, and access to information, are among the key issues on consumer representation currently being debated in the UK context (Simmonds 2002).

Finally, participation of consumer associations in regulation can be understood within the growing attempt to incorporate the concerns and voices of the poor to the processes of policy making. However, as such, participation in regulation would encounter at least the same set of problems that consumer participation in other spheres would; for example:

12 It is not the intention of this study to analyse the effectiveness of the model of consumer representation applied in the UK although some authors have suggested that consumer voice is weak in British regulation (see Baldwin and Cave 1999). Our aim is to provide an example of the arrangement in practice in a country that has been extremely influential in the process of utility reform. 
- who participates;

- how to introduce contestability among consumer associations;

- how to empower (give decision making power) them;

- how to avoid self-exclusion;

- how to overcome the weaknesses of consumer associations for policy analysis, etc.

The last is a very important issue, as utilities are technically complex areas and '...knowledge barriers can undermine citizen engagement unless they equip themselves with substantial technical skills - and then only to provide alternative design and delivery suggestions, not to engage directly in service planning' (Goetz, and Gaventa 2001:56). Once again, it is useful to note that in the case of the UK there is a long tradition of specialized consumer organizations. The UK type of sector-specific consumer organizations are seldom encountered anywhere else in Europe. These organizations are typically established by the government with specific legal status. The existence of consumer organizations is certainly an advantage when it comes to institutionalizing representation of consumer interests in the process of regulation.

Finally, it is important to recognise that regulation is a process where the difference in bargaining power of different actors is explicit and interests are sometimes conflicting. In that context, participation of consumers may run a danger of becoming just a technical device to validate decisions that perpetuate precisely these unequal power relations unless these interests are properly identified and effective mechanisms to render the process accountable are put in place.

\section{Regulation in Latin America: institutional and political factors}

Given that regulation is such an important element for the success of the overall privatization experience, we must ask about the chances for achieving effective regulation. One of the main risks associated with regulatory independence is to confound independence with lack of accountability. This is a mistake that can be easily perpetrated because there is no tradition of independent institutions in Latin America. In addition to that, with privatization the traditional notion of accountability that held the state responsible for the provision of services is no longer valid. The situation is further complicated in the case of utilities because of the presence of the regulator. Who is now accountable - the private operator or the regulator - to ensure access and affordability of services?

There is also evidence that the information is not widely available for consumers and that the process of consultation with civil society is very imperfect. Having consumers represented at the negotiations may enhance transparency. However, the need for transparency will also be evident within the agency. ${ }^{13}$ Measures to enhance transparency

13 Transparency is also crucial to ensure that the process of negotiation achieves outcomes reflecting legitimate bills of all the parties. Once a consumer representative is in the process of regulation, it has to be given access to all information. If all relevant parties do not share the information one of them could mistakenly conclude that the others are defecting from the optimal strategy which is comply with regulations and may decide to retaliate with resulting loss of efficiency like in the standard prisoner's dilemma (Ayers and Braithwaite 1996). 
of the whole regulatory process would help to infuse a more democratic feeling to it. This would also serve to counterbalance the complaint of policy decision making (which affects everyday life) being left in the hands of nonelected technocrats. It is useful to note that effective regulation and independence are not synonymous. The experience of developed countries show that there is a variety of arrangements and conditions that in the absence of an 'independent' regulator could still ensure the effectiveness of the process. In particular, a regulator that operates in a transparent and predictable way could be more effective than an independent regulator that is prone to capture (see Stern 1997).

We would like to stress that the difficulties of regulation are, in part, due to the complex nature of the actors involved in the provision of services. In the first place, the relatively recent experiences of decentralization and devolution of responsibilities to lower levels of government have assigned responsibility for service provision to local governments. Second, the private sector can be either national or foreign, for profit or nonprofit. It is therefore a real challenge to devise fair regulatory mechanisms and to strike a balance among the sometimes conflicting interests of all these actors and consumers. It is important to recognize that regulation is not designed to, nor does it, operate in a vacuum. It reflects a number of elements emerging from the political arena. Many Latin American countries introduced reforms without prior democratic consultation, and the way privatization took place did not help to build up political support for regulation. The reforms in the utilities sector were affected by pressure from international organizations that clearly influenced the pace of the reform process.

The transformation of SOEs into private utilities having a multiparty regulator has great democratic potential. It may help to circumvent the power of strong Latin American executives. Regulation needs to incorporate consumers as stakeholders in the reform process with welcome additional mechanisms to empower them. Citizens should be able to take action in case their expectations are not fulfilled. Consumer participation in regulation could ideally advocate distribution of monopoly rents. Another area in which consumer participation could be hugely important (which is not developed in this study) is the definition of standards of services to be provided. However, we have to be aware that the propensity to participate in most forms of public activities, including regulation, increases with income and education. All the arguments presented in this study are static. We do not consider that in a dynamic context, participation in the regulatory process is likely to be an endogenous factor, linked to access to the services itself and the accumulation of human capital. On the other hand, a lack of qualified staff is also potentially a threat to efficient regulation policy and concomitant activities. Administrative capacity is needed to devise and implement regulation.

Regulation so far has been successful in providing investors the necessary guarantees against administrative expropriation, and in achieving the targets stipulated in the privatization deals. Huge increases in efficiency have been verified so far. However, the main question mark remains whether these efficiency gains will be translated into lower charges that would especially benefit low-income consumers. 


\section{References}

Armstrong, M., S. Cowan, and J. Vickers (1995) Regulatory Reform: Economic Analysis and British Experience, MIT Press: Cambridge MA.

Arocena, P. (2003) 'The Reform of the Utilities Sector in Spain', in C. Ugaz and C. Waddams Price (eds) (2003) Utility Privatization and Regulation: A Fair Deal for Consumers?, Edward Elgar: Cheltenham.

Ayres, I. and J. Braithwaite (1992) Responsive Regulation: Transcending the Deregulation Debate, Oxford University Press: Oxford.

Ayres, I. and J. Braithwaite (1996) 'Supply Side Inefficiencies and Competitive Federalism', in J. McCahery et al. (eds) International Regulatory Competition and Coordination: Perspectives on Economic Regulation in Europe and the United States, Oxford University Press: Oxford.

Baldwin, R. and M. Cave (1999) Understanding Regulation: Theory, Strategy, and Practice, Oxford University Press: Oxford.

Barja, G. and M. Urquiola (2003) 'Capitalization, Regulation and the Poor: Access toBasic Services in Bolivia', in C. Ugaz and C. Waddams Price (eds) Utility Privatization and Regulation: A Fair Deal for Consumers?, Edward Elgar: Cheltenham.

Blinder, A. (1997) 'Is Government Too Political?', Foreign Affairs 76(6): November/December.

Blinder, A. (1998) Central Banking in Theory and Practice, MIT Press: Cambridge MA.

Chisari, O., A. Estache and C. Waddams Price (2003) 'Access by the Poor in Latin America's Utility Reform', in C. Ugaz and C. Waddams Price (eds) (2003) Utility Privatization and Regulation: A Fair Deal for Consumers?, Edward Elgar: Cheltenham.

El Comercio (2001) 'Un Factor que causa Controversias', $10^{\text {th }}$ June.

Delfino, J. and A. Casarin (2003) The Reform of the Utilities Sector in Argentina', in C. Ugaz and C. Waddams Price (eds) (2003) Utility Privatization and Regulation: A Fair Deal for Consumers?, Edward Elgar: Cheltenham.

Devereaux, S. and S. Cook (2000) 'Does Social Policy Meet Social Needs?' IDS Bulletin 31(4): October.

Drazen, A. (2000) Political Economy in Macroeconomics, Princeton University Press: Princeton NJ.

Ewing, A., and S. Goldmark (1994) 'Privatization by Capitalization, the Case of Bolivia: A Popular Participation Recipe for Cash-Starved SOEs', Public Policy for the Private Sector Viewpoint 31, World Bank: Washington DC.

Fernández Ordoñez, M.A. (1997) 'El Papel de la Agencia Reguladora Independiente', Economía Industri, 316.

Goetz, A.M and J. Gaventa (2001) Bringing Citizens Voice and Client Focus into Service Delivery, IDS Working Papers 138.

Gestion (2001) 'Concesionario de Telefonia puede obtener Mayores Utilidades con Factor de Productividad', $18^{\text {th }}$ June.

GRADE (Grupo de Análisis para el Desarrollo-Group for the Analysis of Development) (2001) Tarifas Telefonicas: La Discusion sobre el Factor de Productividad (July), taken from: www.grade.org.pe. 
Guash, J.L. and P. Spiller (1999) 'Managing the Regulatory Process: Design, Concepts, Issues, and the Latin America and Caribbean Story', World Bank Latin American and Caribbean Studies Viewpoints, World Bank: Washington DC.

Loftus, A. and D. McDonald (2001) 'Of Liquid Dreams: A Political Ecology of Water Privatization in Buenos Aires', Environment and Urbanization 13(2): October.

North, D. (1997) 'The Contribution of the New Institutional Economics to an Understanding of the Transition Problem', WIDER Annual Lectures 1, UNU/WIDER: Helsinki.

Offe, C. (1996) 'Designing Institutions in East European Transitions', in R. Goodin (ed.), The Theory of Institutional Design, Cambridge University Press: Cambridge.

Schwartz, K., M. Blokland, A. Nigam and B. Guija (2001) 'Privatization of Water in Developing Countries: Implications for the Poor and Nature' (mimeo), a study sponsored jointly by WWF, UNICEF and IHE (January).

Simmonds, G. (2002) 'Consumer Representation in Europe Policy and Practice for the Utilities and Network Industries. Part I: Consumer Representation in the UK', Centre for the Study of Regulated Industries Research Report 11, University of Bath School of Management.

SIRESE (1994) see: www.sirese.gov.bo/marcolegal/general/ley.

Smith, W. (1997) 'The Utility Regulators: The Independence Debate', Public Policy for the Private Sector Note 127, Finance, Private Sector and Infrastructure Network, World Bank: Washington DC.

Spiller, P. (1995) 'Regulatory Commitment and Utilities' Privatization: Implications for Future Comparative Research', in J. Banks, and E. Hanushek (eds) Modern Political Economy: Old Topics, New Directions, Cambridge University Press: Cambridge MA.

Spiller, P. (1996) 'How Should it Be Done: Electricity Regulation in Argentina, Brazil, Uruguay and Chile', in R. Gilbert and E. Kahn (eds) International Comparisons of Electricity Regulation, Cambridge University Press: Cambridge.

Spiller, P. and W. Savedoff (1999) 'Commitment and Governance in Infrastructure', in F. Basañes, E. Uribe, and R. Willig (eds) Can Privatization Deliver? Infrastructure for Latin America, InterAmerican Development Bank: Washington DC.

Stern, J. (1997) 'What makes an Independent Regulator Independent?', in Business Strategy Review 8(2):67-74.

Stern, J., and S. Holder (1999) 'Regulatory Governance: Criteria for Assessing the Performance of Regulatory Systems: An Application to Infrastructure Industries in the Developing Countries of Asia', Utilities Policy 8:33-50.

Tandon, R. (2002) 'Linking Citizenship, Participation and Accountability: A Perspective from PRIA', IDS Bulletin 33(2): April.

Torero, M. (2000) 'Logros y Retos en el Sector de las Telecomunicaciones: un balance a seis anos de la privatizacion', Analisis y Propuestas: Contribuciones al Debate sobre la Formulacion de Politicas Publicas, GRADE: Lima.

Ugaz, C., and C. Waddams Price (2003) Utility Privatization and Regulation: A Fair Deal for Consumers?, Edward Elgar: Cheltenham.

Waddams Price, C. and A. Young (2003) 'UK Utility Reform: Distributional Implications and Government Response', in C. Ugaz and C. Waddams Price (eds) (2003) Utility Privatization and Regulation: A Fair Deal for Consumers?, Edward Elgar: Cheltenham. 